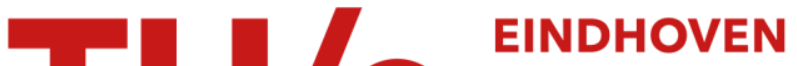 UNIVERSITY OF TECHNOLOGY
}

\section{A systematic review of prenatal screening for congenital heart disease by fetal electrocardiography}

\section{Citation for published version (APA):}

Verdurmen, K. M. J., Eijsvoogel, N., Lempersz, C., Vullings, R., Schroer, C., van Laar, J. O. E. H., \& Oei, S. G. (2016). A systematic review of prenatal screening for congenital heart disease by fetal electrocardiography. International Journal of Gynaecology and Obstetrics, 135(2), 129-134. https://doi.org/10.1016/j.ijgo.2016.05.010

\section{Document license: \\ TAVERNE}

DOI:

10.1016/j.ijgo.2016.05.010

\section{Document status and date:}

Published: 01/01/2016

\section{Document Version:}

Publisher's PDF, also known as Version of Record (includes final page, issue and volume numbers)

\section{Please check the document version of this publication:}

- A submitted manuscript is the version of the article upon submission and before peer-review. There can be important differences between the submitted version and the official published version of record. People interested in the research are advised to contact the author for the final version of the publication, or visit the $\mathrm{DOI}$ to the publisher's website.

- The final author version and the galley proof are versions of the publication after peer review.

- The final published version features the final layout of the paper including the volume, issue and page numbers.

Link to publication

\section{General rights}

Copyright and moral rights for the publications made accessible in the public portal are retained by the authors and/or other copyright owners and it is a condition of accessing publications that users recognise and abide by the legal requirements associated with these rights.

- Users may download and print one copy of any publication from the public portal for the purpose of private study or research.

- You may not further distribute the material or use it for any profit-making activity or commercial gain

- You may freely distribute the URL identifying the publication in the public portal.

If the publication is distributed under the terms of Article 25fa of the Dutch Copyright Act, indicated by the "Taverne" license above, please follow below link for the End User Agreement:

www.tue.nl/taverne

Take down policy

If you believe that this document breaches copyright please contact us at:

openaccess@tue.nl

providing details and we will investigate your claim. 


\title{
A systematic review of prenatal screening for congenital heart disease by fetal electrocardiography
}

\author{
Kim M.J. Verdurmen ${ }^{\mathrm{a}, *}$, Noortje B. Eijsvoogel ${ }^{\mathrm{a}}$, Carlijn Lempersz ${ }^{\mathrm{a}}$, Rik Vullings ${ }^{\mathrm{b}}$, Christian Schroer $^{\mathrm{c}}$, \\ Judith O.E.H. van Laar ${ }^{\text {b }}$, S. Guid Oei ${ }^{\mathrm{a}, \mathrm{b}}$ \\ a Department of Obstetrics and Gynecology, Máxima Medical Center, Veldhoven, Netherlands \\ ${ }^{\mathrm{b}}$ Faculty of Electrical Engineering, Eindhoven University of Technology, Eindhoven, Netherlands \\ c Department of Pediatrics, Máxima Medical Center, Veldhoven, Netherlands
}

\section{A R T I C L E I N F O}

\section{Article history:}

Received 2 February 2016

Received in revised form 21 May 2016

Accepted 27 July 2016

\section{Keywords:}

Congenital heart disease

Fetal electrocardiography

Fetal electrocardiogram

Prenatal diagnosis

Prenatal screening

\begin{abstract}
A B S T R A C T
Background: Congenital heart disease (CHD) is the most common severe congenital anomaly worldwide. Diagnosis early in pregnancy is important, but the detection rate by two-dimensional ultrasonography is only 65\%-81\%. Objectives: To evaluate existing data on CHD and noninvasive abdominal fetal electrocardiography (ECG). Search strategy: A systematic review was performed through a search of the Cochrane Library, PubMed, and Embase for studies published up to April 2016 using the terms "congenital heart disease," "fetal electrocardiogram," and other similar keywords. Selection criteria: Primary articles that described changes in fetal ECG among fetuses with CHD published in English were included. Data collection and analysis: Outcomes of interest were changes in fetal ECG parameters observed for fetuses with congenital heart disease. Findings were reported descriptively. Main results: Only five studies described changes observed in the fetal electrocardiogram for fetuses with CHD, including heart rate, heart rate variability, and PR, QRS, and QT intervals. Fetal ECG reflects the intimate relationship between the cardiac nerve conduction system and the structural morphology of the heart. It seems particularly helpful in detecting the electrophysiological effects of cardiac anatomic defects (e.g. hypotrophy, hypertrophy, and conduction interruption). Conclusions: Fetal ECG might be a promising clinical tool to complement ultrasonography in the screening program for CHD.
\end{abstract}

(C) 2016 International Federation of Gynecology and Obstetrics. Published by Elsevier Ireland Ltd. All rights reserved.

\section{Introduction}

Congenital heart disease (CHD) is the most common severe congenital anomaly worldwide [1]. It has been defined as "a gross structural abnormality of the heart or intra-thoracic large vessels that is actually or potentially of functional significance" [2]. Major CHD is usually defined as a form of CHD that is lethal or requires intervention in the first year of life. The incidence of $\mathrm{CHD}$ is estimated at $6-12$ cases per 1000 live births ( 4 cases of major CHD per 1000 live births), which makes this disorder six times more common than chromosomal anomalies and four times more common than neural tube defects [3-5]. In Europe, the overall rate of mortality due to CHD (both perinatal deaths and termination of pregnancy) was 0.7 per 1000 births in 2000-2005 [6]. Of the fetuses affected by CHD, $4.5 \%$ die in utero and $21.1 \%$ die after birth [7].

Diagnosing CHD early in pregnancy enables the identification of associated extracardiac anomalies (present in $29 \%$ of cases) and

\footnotetext{
* Corresponding author at: Department of Obstetrics and Gynecology, Máxima Medical Center, Veldhoven, PO Box 7777, 5500 MB Veldhoven, Netherlands. Tel.: + 3140888 8380; fax: + 31408889564

E-mail address: kimverdurmen@live.nl (K.M.J. Verdurmen).
}

chromosomal anomalies (26\% of cases) that have an effect on fetal and postnatal prognosis [8]. Prenatal and genetic counselling by experts can be offered to parents. Thereafter, parents can decide to terminate or continue with the pregnancy. Studies $[8,9]$ have shown that the frequency of pregnancy termination is higher if prenatal diagnosis is made at an earlier gestational age (61\% and $44 \%$ at 19 and 24 weeks of pregnancy, respectively). If pregnancy is continued, an adequate plan of management can be developed, including intrauterine therapy, timing, mode and location of delivery, and immediate treatment after birth. It has been demonstrated that prenatal diagnosis of CHD increases survival rates and decreases long-term morbidity in both ductus-dependent and foramen ovale-dependent CHD [9-12]. As Yates [13] has pointed out, however, prenatally diagnosed CHD often has a worse prognosis because it is more likely to be severe (i.e. easier to detect by ultrasonography) or associated with extracardiac or chromosomal anomalies.

Fetal cardiac screening during the second trimester was standardized in 2006 [14]. The detection rate of CHD varies widely, from 65\% to $81 \%$ [15-18]. The challenges encountered include the complex anatomy of the fetal heart, its motion, and small size. Specific echocardiography is performed for fetuses with risk factors for CHD, and this technique has a higher detection rate (sensitivity 90\%, specificity 98\%) [19]. 
However, up to $90 \%$ of all cases of CHD occur in the low-risk population $[3,4,20-22]$, indicating the necessity of an effective screening procedure that is available to all pregnant women.

Therefore, there is need for a reliable noninvasive diagnostic method with improved predictive value for the diagnosis of CHD. Noninvasive transabdominal fetal electrocardiography (fetal ECG) is a new field that is being investigated. This technique can be used early in pregnancy (from 18 weeks), is safe to use, and easy to apply [23]. A big advantage is that fetal ECG is a potentially non-expensive long-term diagnostic tool, and raw data can be forwarded for evaluation elsewhere.

Extraction of fetal ECG data was first described in 1906 by Cremer [24], and the approach was first reviewed in 1986 by Pardi et al. [25]. Despite this early documentation, the development of fetal ECG has lagged behind other techniques for fetal monitoring, partly because of technical challenges. The fetal signal has low amplitude (2-50 microvolts, $1 / 50$ th of the maternal ECG), and is masked by both the maternal electrocardiogram and background noises (maternal electromyogram), resulting in a low signal-to-noise ratio $[25,26]$. The fetus is surrounded by amniotic fluid and maternal tissues, which enlarge the distance to the electrodes and cause a non-homogenous tissue conduction that interferes with signal quality. Additionally, the vernix caseosa is electrically isolating and a main cause of the poor signal-to-noise ratio from 30 to 34 gestational weeks $[23,27]$. Other challenging factors are the complex three-dimensional form of the fetal electrocardiogram and the movements of the fetus, which makes it difficult to evaluate the heart from one direction. Furthermore, at 20 gestational weeks, the fetal heart is approximately one-tenth of the size of an adult heart and the fetal heart rate is two to three times faster than the adult heart rate [28]. With improvements in technology and knowledge of information theory, however, fetal ECG is becoming more and more attractive.

In addition to the challenges in the conduct of fetal ECG, it is also difficult to interpret the data. By contrast with postnatal life, the systemic circulation in the fetus is fed from the left and right ventricles in parallel with equal intraventricular pressure [29]. The right ventricular outflow is slightly larger than the left ventricular outflow. The ductus arteriosus propels $40 \%$ of the combined cardiac output during the second trimester. Right-sided obstructive lesions (e.g. tetralogy of Fallot or pulmonary stenosis) with a dominance of the right ventricle are difficult to diagnose in utero; however, they are often accompanied by septal defects or by left-side obstructive lesions (e.g. aortic stenosis or coarctation of the aorta), which can be detected more easily. Owing to the fetal circulation in utero, fetuses affected by CHD do not always show overt signs of cardiac failure, because one side of the heart can compensate for an abnormality on the other side. At present, the changes in the fetal ECG amplitudes, segment intervals, and heart axis that are characteristic of CHD are not known. Although the changes due to CHD seen on neonatal ECG are documented, these data are not likely to correspond with those of fetal ECG because the circulation changes markedly directly after birth. The aim of the present review was to evaluate the existing data on CHD and noninvasive abdominal fetal ECG.

\section{Materials and methods}

As part of a systematic review, the Cochrane Library (2016, Issue 4), PubMed, and Embase electronic databases were searched to identify all studies published on fetal ECG and CHD up to April 30, 2016. The following keywords were used: "congenital heart disease," "congenital heart defects," "fetal electrocardiogram," "fetal electrocardiography," and "fetal ECG". The outcomes of interest were changes seen in fetal ECG parameters, such as ECG intervals, ECG segments, and the electrical heart axis among fetuses with CHD.

Primary articles that described the changes in fetal ECG among fetuses with CHD were selected. The reference lists of the selected articles were also searched. The study language was restricted to English. Review articles and studies describing diagnostic tools other than noninvasive abdominal fetal ECG were excluded. Articles that solely described fetal arrhythmia were excluded because only few arrhythmias are associated with CHD.

The search and selection of articles were performed independently by two authors (K.M.J.V. and N.B.E.). The guidelines and quality assessment forms of the Dutch Cochrane Center were used to evaluate the quality of the studies. The findings were reported descriptively and no statistical analysis was performed.

\section{Results}

The search and selection of articles is summarized in Fig. 1. In total, five articles met the inclusion criteria and were reviewed, including case reports by Hamilton et al. [30] and Brambati and Bonsignore [31]. Three articles by Siddiqui et al. [32], Velayo et al. [33], and Yilmaz et al. [34] were prospective cohort studies including normal fetuses and cases of CHD. The five studies were published between 1977 and 2016.

Owing to the low numbers of fetuses, the variation in outcome measures described, and the differences in signal processing techniques used in the five studies, it was not possible to directly compare or pool the results. The basic characteristics and a quality assessment of the two case reports are given in Table 1, whereas the basic characteristics and a quality assessment of the prospective studies are given in Tables 2 and 3. Table 4 presents an overview of the fetal ECG parameters of the fetuses with CHD included in the review.

Hamilton et al. [30] described a case of complex CHD, in which a complete heart block was seen in 1977. They used a cardiotocograph with the capacity to process fetal phonocardiographic and abdominal fetal ECG signals. The bizarre QRS complexes found on fetal ECG (not otherwise specified) suggest that the pacemaker was distal to the bundle of His, with a fetal heart rate of 50 beats per minute. After delivery, cardiac catheterization and angiocardiography were performed to confirm the existence of complex CHD (Table 4).

Seven years later, Brambati et al. [31] described a case of an atrioventricular septal defect in which cardiac arrhythmia was seen. The signal processing method is not extensively described, but data extraction was mainly performed manually and a median fetal ECG constituting 50 heartbeats was generated. Extrasystoles without a preceding $\mathrm{P}$ wave were found, suggestive of ventricular origin. Additionally, a prolonged QRS time was found, which was stated to be suspicious of cardiac enlargement and/or a cardiac anomaly. After delivery, ventricular extrasystoles, left axis deviation, and right ventricular

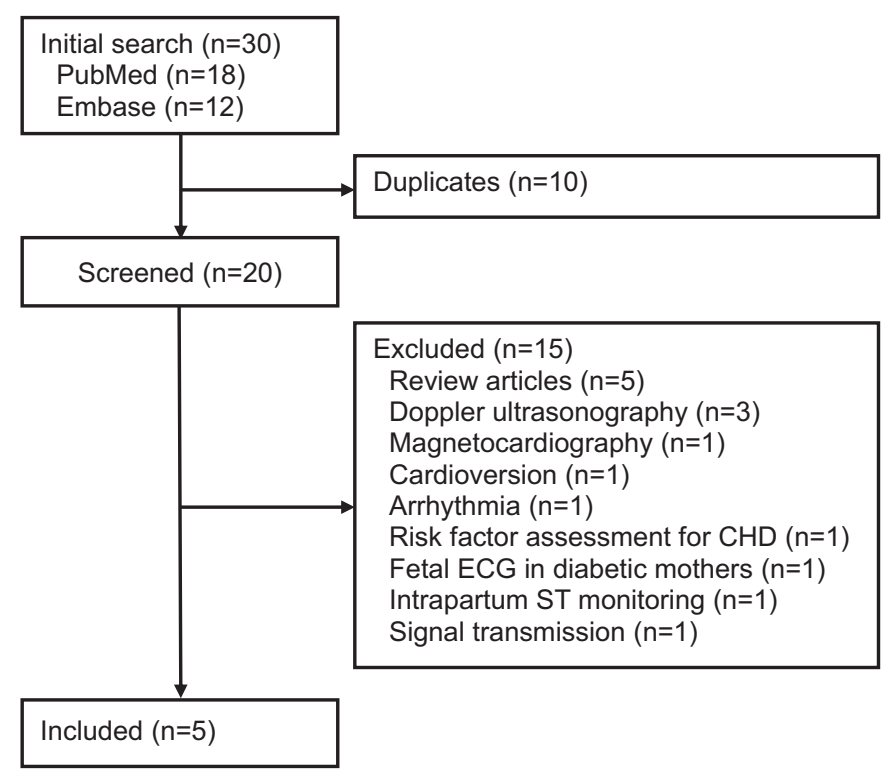

Fig. 1. Flowchart showing the search and selection of articles. Abbreviations: ECG electrocardiography; CHD, congenital heart disease. 
Table 1

Characteristics and quality assessment of the two case reports on fetal ECG.

\begin{tabular}{|c|c|c|}
\hline Characteristic & Hamilton et al. [30] & Brambati et al. [31] \\
\hline Year of publication & 1977 & 1983 \\
\hline Study design & Case report & Case report \\
\hline Number of patients & 1 & 1 \\
\hline Case & Complete fetal heart block & $\begin{array}{l}\text { Fetal cardiac } \\
\text { arrhythmia }\end{array}$ \\
\hline Gestational age, wk & 32 & 34 \\
\hline $\begin{array}{l}\text { Prenatal ultrasonography } \\
\text { screening }\end{array}$ & Not described & Not described \\
\hline $\begin{array}{l}\text { Fetal ECG signal processing } \\
\text { technique }\end{array}$ & Unclear; two leads & Unclear \\
\hline Postnatal diagnostics & $\begin{array}{l}\text { Auscultation, ECG, radiography, } \\
\text { cardiac catheterization/ } \\
\text { angiocardiography, autopsy }\end{array}$ & $\begin{array}{l}\text { Auscultation, ECG, } \\
\text { radiography }\end{array}$ \\
\hline Diagnosis & Multiple cardiac anomalies & $\begin{array}{l}\text { Atrial septal defect, } \\
\text { mitral insufficiency }\end{array}$ \\
\hline
\end{tabular}

Abbreviation: ECG, electrocardiography

hypertrophy were found on ECG. The neonate was diagnosed with an atrioventricular septal defect.

Velayo et al. [33] performed a prospective cohort study using simultaneous fetal ECG and cardiotocography (Doppler ultrasonography) recordings. The fetal heart rate information derived from Doppler ultrasonography was used to filter the fetal ECG [35]. Overall, 179 women were prospectively screened from a low-risk population. Twelve (7\%) showed an abnormal fetal ECG; of these, 8 (4\%) were excluded from further analysis because the fetus had no underlying structural heart defects, whereas $4(2 \%)$ were confirmed to have CHD by an ultrasonography examination performed after inclusion in the study. The remaining 167 women (93\%) with normal fetal ECG and no CHD or other anomalies on ultrasonography evaluation were used for standardization of normal parameters. The fetal ECG was found to have a sensitivity of $100 \%$, specificity of $95 \%$, positive predictive value of $33 \%$, and negative predictive value of $100 \%$ for the detection of $\mathrm{CHD}$ in a low-risk population.

Velayo et al. [33] described the four cases of CHD that they found in their study population in detail (Table 4). They stated that premature ventricular contractions, as seen in cases one and three, might be caused by a primary developmental anomaly of the conduction system in the presence of endocardial cushion defects or an underlying genetic defect affecting intrinsic myocardial cell physiology. Prolongation of the QT interval, as seen in cases two and four, might be explained by repolarization dysfunction (alterations in action potential duration) caused by ventricular aberrations [33]. This is also seen in cases of cardiac remodeling due to disease progression. In case four, the various prolonged intervals might have been late signs of the critical condition of the fetus, supported by the cardiomegaly with signs of heart failure.

Yilmaz et al. [34] and Siddiqui et al. [32] both performed a prospective cohort study of the same set of 92 participants: 41 healthy controls and 51 fetuses with CHD confirmed by fetal echocardiography. A Monica AN24 fetal electrocardiographic monitor was used to perform measurements at three gestational ages (19-27, 28-33 and 34-38 gestational weeks). Tracing quality was analyzed in both studies.

Yilmaz et al. [34] calculated the PR, QRS, and QT intervals during gestation. They showed that the PR and QRS intervals both lengthen as gestational age increases among normal fetuses. Among fetuses with CHD, this lengthening during gestation was not seen, but longer PR and QRS intervals were seen at all gestational ages as compared with normal values (Table 4). T waves seemed to be difficult to detect, and were therefore not included in the analysis.

Siddiqui et al. [32] calculated fetal heart rate and fetal heart rate variability during gestation. Among the control fetuses, heart rate decreased during gestation, whereas heart rate variability increased. Fetuses with CHD generally had a lower fetal heart rate than healthy fetuses, but no differences in heart rate variability at 34-38 weeks were observed between the controls and cases except for fetuses with hypoplastic left heart syndrome (which showed significantly lower heart rate variability during the active fetal state).

\section{Discussion}

Overall, the present systematic review revealed that little research has been published regarding the changes in fetal ECG parameters observed for fetuses with CHD. The methods of conducting the fetal ECG measurements were different in most studies and evolved with time. Additionally, the fetal ECG parameters described in the studies varied. All the studies included show that fetal ECG can be a valuable tool to diagnose CHD early in utero. However, data on the fetal ECG changes observed among fetuses with CHD remain limited.

Both the case reports by Hamilton et al. [30] and Brambati et al. [31] are from another era, and are therefore not comparable with the signal processing techniques in current use. It is not likely that the two pregnancies described received prenatal ultrasonography screening to detect CHD. Nevertheless, both studies do indicate the potential of fetal ECG in diagnosing CHD and fetal arrhythmias.

Velayo et al. [33] reported a promising sensitivity and specificity of $100 \%$ and $95 \%$, respectively; however, the positive predictive value of fetal ECG was only 33\%. This low positive predictive value can be explained by the low probability that fetuses in the general population will have CHD. The eight cases with an abnormal ECG that were excluded had other abnormalities, including non-immune hydrops fetalis,

Table 2

Characteristics and quality assessment of the study by Velayo et al. [33].

\begin{tabular}{|c|c|c|c|c|c|}
\hline Characteristic & Overall & Case 1 & Case 2 & Case 3 & Case 4 \\
\hline Year of publication & 2011 & - & - & - & - \\
\hline Study design & Prospective cohort study & - & - & - & - \\
\hline Inclusion/exclusion criteria & Clear & - & - & - & - \\
\hline Risk of selection bias & High & - & - & - & - \\
\hline Number of patients & 179 & 1 & 1 & 1 & 1 \\
\hline Gestational age, wk & $18-41$ & 23 & 32 & 33 & 28 \\
\hline Prenatal ultrasonography screening & Normal & $\begin{array}{l}\text { Multiple cardiac } \\
\text { anomalies }\end{array}$ & $\begin{array}{l}\text { Multiple cardiac } \\
\text { anomalies }\end{array}$ & $\begin{array}{l}\text { Multiple cardiac } \\
\text { anomalies }\end{array}$ & $\begin{array}{l}\text { Multiple cardiac } \\
\text { anomalies }\end{array}$ \\
\hline Fetal ECG signal processing technique & Clear; 14 leads & & & & \\
\hline Other diagnostics prenatally & None & $\begin{array}{l}\text { Chromosomal } \\
\text { analysis, MRI }\end{array}$ & None & None & None \\
\hline Postnatal diagnosis and/or therapy & Unclear & Surgery & Unclear & Unclear & Unclear \\
\hline Follow-up & Unclear & - & - & - & - \\
\hline Confounders & Unclear & - & - & - & - \\
\hline Available as in clinical practice & Yes & - & - & - & - \\
\hline
\end{tabular}

Abbreviations: ECG, electrocardiography; MRI, magnetic resonance imaging. 
Table 3

Characteristics and quality assessment of the studies by Siddiqui et al. [32] and Yilmaz et al. [34].

\begin{tabular}{|c|c|c|c|c|c|c|c|c|}
\hline \multirow{2}{*}{ Characteristic } & \multicolumn{4}{|l|}{ Yilmaz et al. [34] } & \multicolumn{4}{|l|}{ Siddiqui et al. [32] } \\
\hline & Overall & HLHS & TGA & TOF & Overall & HLHS & TGA & TOF \\
\hline Year of publication & 2016 & - & - & - & 2015 & - & - & - \\
\hline Study design & Prospective cohort study & - & - & - & Prospective cohort study & - & - & - \\
\hline Inclusion/exclusion criteria & Clear & - & - & - & Clear & - & - & - \\
\hline Risk of selection bias & High & - & - & - & High & - & - & - \\
\hline Number of patients & 92 & 15 & 12 & 14 & 92 & 19 & 12 & 20 \\
\hline Gestational age, wk & $20-38$ & $20-38$ & $20-38$ & $20-38$ & $19-38$ & $19-38$ & $19-38$ & $19-38$ \\
\hline Prenatal ultrasonography screening & Yes & - & - & - & Yes & - & - & - \\
\hline Fetal ECG signal processing technique & Clear; 5 leads & - & - & - & Unclear & - & - & - \\
\hline Other diagnostics prenatally & None & - & - & - & None & - & - & - \\
\hline Postnatal diagnosis and/or therapy & Unclear & - & - & - & Unclear & - & - & - \\
\hline Follow-up & Unclear & - & - & - & Unclear & - & - & - \\
\hline Confounders & Unclear & - & - & - & Unclear & - & - & - \\
\hline Available as in clinical practice & Yes & - & - & - & Yes & - & - & - \\
\hline
\end{tabular}

Abbreviations: HLHS, hypoplastic left heart syndrome; TGA, transposition of the great arteries; TOF, tetralogy of Fallot.

hypoxemia, or arrhythmia (not otherwise specified). Although CHD was not detected in this group, it is nonetheless important to identify this subset of fetuses that are possibly at risk of fetal distress [36].

Yilmaz et al. [34] and Siddiqui et al. [32] describe the largest case series of fetal ECG measurements among fetuses with CHD published so far. However, only three types of CHD-which were commonly diagnosed and with "distinct anatomic and physiologic features that could potentially impact ECG intervals" [34]-were included in those studies. As a result, there is a high risk of selection bias in both studies. Additionally, identification of the P, QRS, and T waves is not extensively described by Yilmaz et al. [34]. Siddiqui et al. [32] calculated heart rate variability in three different ways: interquartile range of the fetal heart rate, standard deviation of the fetal heart rate, and root mean square of the standard deviation of the heart rate. Unfortunately, exact values are not given for each type of CHD separately for either fetal heart rate or variability. A new trial with a greater sample population and the inclusion of more types of CHD is needed.

The fetal electrocardiogram reflects the intimate relationship between the cardiac nerve conduction system and the structural morphology of the heart [33]. In accordance with Yilmaz et al. [34], other studies also found that the duration of the P wave, QRS complex, and PR interval increases progressively from 18 gestational weeks until term for fetuses

Table 4

Overview of the fetal ECG parameters observed for fetuses with congenital heart disease.

\begin{tabular}{|c|c|c|c|c|c|c|}
\hline Study & No. ${ }^{a}$ & Type of CHD & Findings fetal ECG (GA, wk) & $\begin{array}{l}\text { PR interval, ms } \\
(\mathrm{GA}, \mathrm{wk})\end{array}$ & $\begin{array}{l}\text { QRS interval, } \\
\text { ms (GA, wk) }\end{array}$ & $\begin{array}{l}\text { QT interval, } \\
\text { ms (GA, wk) }\end{array}$ \\
\hline Hamilton et al. [30] & 1 & Complex ${ }^{\mathrm{b}}$ & $\begin{array}{l}\text { Bizarre QRS complexes; } \\
\text { Complete atrioventricular block; } \\
\text { Atrial rate, } 100 \mathrm{bpm} \text {; } \\
\text { Ventricular rate, } 48 \mathrm{bpm}\end{array}$ & & & \\
\hline Brambati et al. [31] & 1 & $\begin{array}{l}\text { Atrial septal defect, mitral } \\
\text { insufficiency }\end{array}$ & Premature ventricular contractions & & $\begin{array}{l}\text { Extrasystole: } 112 \pm 22(34) \\
\text { Normal complex: } 72 \pm 9(34)\end{array}$ & \\
\hline Velayo et al. [33] & 1 & $\begin{array}{l}\text { Case 1: Atrioventricular } \\
\text { septal defect }\end{array}$ & $\begin{array}{l}\text { Premature ventricular contractions; } \\
\text { Right axis deviation }\end{array}$ & & & \\
\hline Velayo et al. [33] & 1 & Case 2: Complex ${ }^{\mathrm{c}}$ & & & & QTc, 518 (32) \\
\hline Velayo et al. [33] & 1 & Case 3: Complex ${ }^{\mathrm{d}}$ & $\begin{array}{l}\text { Polymorphic premature ventricular } \\
\text { contractions; } \\
\text { Prolonged pre-ejection period }\end{array}$ & & & \\
\hline Velayo et al. [33] & 1 & Case 4: Complex ${ }^{\mathrm{e}}$ & Prolonged pre-ejection period & $115(33)$ & & QTc, 445 (33) \\
\hline Yilmaz et al. [34] & $13-23$ & Controls & $\mathrm{HR}, 148 \pm 4 \mathrm{bpm}(19-27)$ & $93 \pm 12(20-24)$ & $52 \pm 5(20-24)$ & $240 \pm 15(20-24)$ \\
\hline Siddiqui et al. [32] & & & $\begin{array}{l}\mathrm{HR}, 141 \pm 3 \mathrm{bpm}(28-33) \\
\mathrm{SD}, 0.020 \pm 0.002(34-38)\end{array}$ & $\begin{array}{l}102 \pm 15(28-32) \\
109 \pm 18(34-38)\end{array}$ & $\begin{array}{l}56 \pm 7(28-32) \\
56 \pm 9(34-38)\end{array}$ & $\begin{array}{l}231 \pm 41(28-32) \\
233 \pm 43(34-38)\end{array}$ \\
\hline Siddiqui et al. [32] & 22 & All CHD & $\mathrm{HR}, 143 \pm 5$ bpm (19-27) & & & \\
\hline $\begin{array}{l}\text { Yilmaz et al. [34] } \\
\text { Siddiqui et al. [32] }\end{array}$ & $5-9$ & $\begin{array}{l}\text { Hypoplastic left heart } \\
\text { syndrome }\end{array}$ & $\begin{array}{l}\mathrm{HR}, 143 \pm 3 \mathrm{bpm}(19-27) \\
\mathrm{HR}, 136 \pm 5 \mathrm{bpm}(28-33) \\
\mathrm{SD}, 0.013 \pm 0.003(34-38)\end{array}$ & $\begin{array}{l}97 \pm 16(20-24) \\
113 \pm 12(28-32) \\
120 \pm 21(34-38)\end{array}$ & $\begin{array}{l}66 \pm 6(20-24) \\
62 \pm 7(28-32) \\
61 \pm 16(34-38)\end{array}$ & \\
\hline $\begin{array}{l}\text { Yilmaz et al. [34] } \\
\text { Siddiqui et al. [32] }\end{array}$ & $2-10$ & Tetralogy of Fallot & $\mathrm{HR}, 140 \pm 7$ bpm (19-27) & $\begin{array}{l}119 \pm 29(20-24) \\
105 \pm 14(28-32) \\
113 \pm 21(34-38)\end{array}$ & $\begin{array}{l}61 \pm 3(20-24) \\
59 \pm 9(28-32) \\
67 \pm 5(34-38)\end{array}$ & \\
\hline $\begin{array}{l}\text { Yilmaz et al. [34] } \\
\text { Siddiqui et al. [32] }\end{array}$ & $4-9$ & $\begin{array}{l}\text { Transposition of the } \\
\text { great arteries }\end{array}$ & & $\begin{array}{l}92 \pm 21(20-24) \\
101 \pm 10(28-32) \\
101 \pm 20(34-38)\end{array}$ & $\begin{array}{l}60 \pm 2(20-24) \\
64 \pm 9(28-32) \\
64 \pm 8(34-38)\end{array}$ & \\
\hline
\end{tabular}

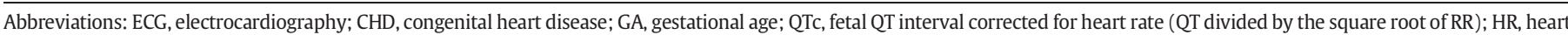
rate; $\mathrm{SD}$, standard deviation of heart rate during active fetal state (i.e. heart rate variability); bpm, beats per minute.

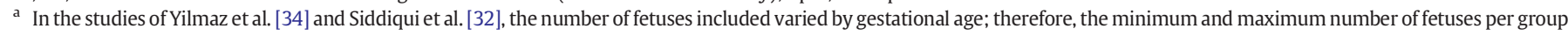
is indicated.

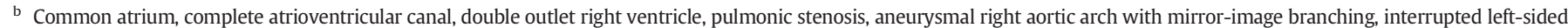
vena cava with azygous continuation.

c Total anomalous pulmonary venous connection, pulmonic stenosis, systemic right ventricular dysfunction, common atrioventricular valve, bilateral superior vena cava, pulmonary venous return anomaly.

d Tetralogy of Fallot, ventricular septal defect, pulmonic stenosis, double outlet right ventricle, transposition of the great arteries, multi-aortopulmonary collateral arteries.

e Dilated cardiomyopathy, ventricular septal defect, congestive heart failure. 
with normal cardiac structures [36,37]. This reflects the anatomic development of the atria and ventricles during pregnancy, with a gain in the weight and mass of the fetal heart. The increase in PR interval indicates the development of the atrioventricular conducting tissue [38].

Yilmaz et al. [34] showed that, among fetuses with CHD, the normal lengthening in PR and QRS intervals during pregnancy is absent. Additionally, most CHDs are associated with an increased or decreased ventricular mass or cardiac arrhythmias $[25,30,31,33]$. In the case of a severe endocardial cushion defect (atrioventricular septum defect), the abnormal atrioventricular connection affects the conduction system, and this is reflected in a longer PR interval and left axis deviation [25,31,33,39].

The aim of Siddiqui et al. [32] was to characterize autonomic regulation in fetuses with CHD, and to study whether autonomic development is altered by comparison with healthy controls. Although it was not the aim, the study seems to indicate that heart rate variability might not be a good screening tool to detect CHD because heart rate variability was lower only among fetuses with hypoplastic left heart syndrome and only in the measurement at 34-38 gestational weeks. Moreover, there were only minor differences in fetal heart rate between controls and fetuses with CHD.

The rate of prenatal detection by two-dimensional ultrasonography is mainly influenced by the experience of the sonographer. It is relatively difficult to interpret the anatomy of the fetal heart correctly because it is a dynamic, constantly moving structure that rhythmically beats approximately more than twice per second. In addition, some diagnoses (e.g. coarctation of the aorta and CHDs that develop/progress during pregnancy such as pulmonary stenosis, aortic stenosis, ventricular hypoplasia, and cardiomyopathy) remain challenging to diagnose even in experienced centers. Given the fetal circulation, it is difficult to define lesion severity in the presence of the unique fetal shunts that permit redistribution of ventricular preload and output to the contralateral ventricle or great artery [3].

Computerized evaluation of the fetal electrocardiogram might eliminate some of the above-mentioned problems. First, performer variability-as occurs in the case of ultrasonography-would be absent because the data are analyzed by computerized algorithms. Second, the equipment is cheaper and smaller by comparison with ultrasonography equipment. Third, application of the fetal ECG system involves minimum training. Last, at the time of the fetal anomaly scan, CHDs that evolve during gestation might present no anomalies by ultrasonography, but might show fetal ECG characteristics.

The present review has some limitations. Because little research has been published, the amount of ECG recordings that was available per type of CHD was limited. Only two case reports and three prospective trials were found. The methods of conducting the fetal ECG measurements were different in the five studies and evolved during time. Additionally, the fetal ECG parameters that were described varied in every study. Nevertheless, all the studies included show that fetal ECG can be a valuable tool for diagnosing CHD early in utero.

In conclusion, fetal ECG is a promising clinical tool that complements ultrasonography in the screening program for CHD. It is particularly suitable for the detection of secondary effects due to CHD (i.e. hypotrophy, hypertrophy, and conduction interruption). However, more research establishing normal fetal ECG values and studies concerning the true incidence of fetal ECG anomalies in CHD are needed.

\section{Acknowledgments}

The research was performed within the IMPULS Perinatology framework (Netherlands).

\section{Conflicts of interest}

The authors have no conflicts of interest.

\section{References}

[1] van der Linde D, Konings EE, Slager MA, Witsenburg M, Helbing WA, Takkenberg JJ, et al. Birth prevalence of congenital heart disease worldwide: a systematic review and meta-analysis. J Am Coll Cardiol 2011;58(21):2241-7.

[2] Mitchell SC, Korones SB, Berendes HW. Congenital heart disease in 56,109 births. Incidence and natural history. Circulation 1971;43(3):323-32.

[3] Donofrio MT, Moon-Grady AJ, Hornberger LK, Copel JA, Sklansky MS, Abuhamad A, et al. Diagnosis and treatment of fetal cardiac disease: a scientific statement from the American Heart Association. Circulation 2014;129(21):2183-242.

[4] Simpson LL. Screening for congenital heart disease. Obstet Gynecol Clin North Am 2004;31(1):51-9.

[5] Gardiner HM. Keeping abreast of advances in fetal cardiology. Early Hum Dev 2006; 82(6):415-9.

[6] Dolk H, Loane M, Garne E. European Surveillance of Congenital Anomalies (EUROCAT) Working Group. Congenital heart defects in Europe: prevalence and perinatal mortality, 2000 to 2005. Circulation 2011;123(8):841-9.

[7] Fesslova' V, Brankovic J, Boschetto C, Masini A, Prandstraller D, Perolo A, et al. Changed outcomes of fetuses with congenital heart disease: new Italian Multicentre study. J Cardiovasc Med (Hagerstown) 2015;16(8):568-75.

[8] Clur SA, Van Brussel PM, Mathijssen IB, Pajkrt E, Ottenkamp J, Bilardo CM. Audit of 10 years of referrals for fetal echocardiography. Prenat Diagn 2011;31(12):1134-40.

[9] Trines J, Fruitman D, Zuo KJ, Smallhorn JF, Hornberger LK, Mackie AS. Effectiveness of prenatal screening for congenital heart disease: assessment in a jurisdiction with universal access to health care. Can J Cardiol 2013;29(7):879-85.

[10] Brick DH, Allan LD. Outcome of prenatally diagnosed congenital heart disease: an update. Pediatr Cardiol 2002;23(4):449-53.

[11] Hunter LE, Simpson JM. Prenatal screening for structural congenital heart disease. Nat Rev Cardiol 2014;11(6):323-34.

[12] Brown KL, Ridout DA, Hoskote A, Verhulst L, Ricci M, Bull C. Delayed diagnosis of congenital heart disease worsens preoperative condition and outcome of surgery in neonates. Heart 2006;92(9):1298-302.

[13] Yates RS. The influence of prenatal diagnosis on postnatal outcome in patients with structural congenital heart disease. Prenat Diagn 2004;24(13):1143-9.

[14] International Society of Ultrasound in Obstetrics and Gynecology. Cardiac screening examination of the fetus: guidelines for performing the 'basic' and 'extended basic' cardiac scan. Ultrasound Obstet Gynecol 2006;27(1):107-13.

[15] Carvalho JS, Mavrides E, Shinebourne EA, Campbell S, Thilaganathan B. Improving the effectiveness of routine prenatal screening for major congenital heart defects. Heart 2002;88(4):387-91.

[16] Kirk JS, Riggs TW, Comstock CH, Lee W, Yang SS, Weinhouse E. Prenatal screening for cardiac anomalies: the value of routine addition of the aortic root to the fourchamber view. Obstet Gynecol 1994;84(3):427-31.

[17] Oggè G, Gaglioti P, Maccanti S, Faggiano F, Todros T. Prenatal screening for congenital heart disease with four-chamber and outflow-tract views: a multicenter study. Ultrasound Obstet Gynecol 2006;28(6):779-84.

[18] Wu Q Li M, Ju L, Zhang W, Yang X, Yan Y, et al. Application of the 3-vessel view in routine prenatal sonographic screening for congenital heart disease. J Ultrasound Med 2009;28(10):1319-24.

[19] Cohen EH, Rein AJ. Antenatal diagnosis of cardiac malformation: a structural study. Fetal Diagn Ther 2000;15(1):54-60.

[20] Galindo A, Herraiz I, Escribano D, Lora D, Melchor JC, de la Cruz J. Prenatal detection of congenital heart defects: a survey on clinical practice in Spain. Fetal Diagn Ther 2011;29(4):287-95.

[21] Rocha LA, Araujo Júnior E, Nardozza LM, Moron AF. Screening of fetal congenital heart disease: the challenge continues. Rev Bras Cir Cardiovasc 2013;28(3):V-VII.

[22] Achiron R, Glaser J, Gelernter I, Hegesh J, Yagel S. Extended fetal echocardiographic examination for detecting cardiac malformations in low risk pregnancies. BMJ 1992;304(6828):671-4.

[23] van Laar JO, Warmerdam GJ, Verdurmen KM, Vullings R, Peters CH, Houterman S, et al. Fetal heart rate variability during pregnancy, obtained from non-invasive electrocardiogram recordings. Acta Obstet Gynecol Scand 2014;93(1):93-101.

[24] Cremer M. About the direct derivation of the action currents of the human heart from the esophagus and about the electrocardiogram of the fetus [in German]. Münch Med Wschr 1906:53:811-3.

[25] Pardi G, Ferrazzi E, Cetin I, Rampello S, Baselli G, Cerutti S, et al. The clinical relevance of the abdominal fetal electrocardiogram. J Perinat Med 1986;14(6):371-7.

[26] Kimura Y, Sato N, Sugawara J, Velayo C, Hoshiai T, Nagase S, et al. Recent advances in fetal electrocardiography. Open Med Device J 2012;4:7-12.

[27] Oostendorp TF, van Oosterom A, Jongsma HW. The fetal ECG throughout the second half of gestation. Clin Phys Physiol Meas 1989;10(2):147-60.

[28] Van Mieghem T, DeKoninck P, Steenhaut P, Deprest J. Methods for prenatal assessment of fetal cardiac function. Prenat Diagn 2009;29(13):1193-203.

[29] Kiserud T, Acharya G. The fetal circulation. Prenat Diagn 2004;24(13):1049-59.

[30] Hamilton Jr LA, Fisher E, Horn C, DuBrow I, Vidyasagar D. A new prenatal cardiac diagnostic device for congenital heart disease. Obstet Gynecol 1977;50(4):491-4.

[31] Brambati B, Bonsignore L. The significance of indirect electrocardiography in fetal cardiac arrhythmias. Eur J Obstet Gynecol Reprod Biol 1983;14(6):371-3.

[32] Siddiqui S, Wilpers A, Myers M, Nugent JD, Fifer WP, Williams IA. Autonomic regulation in fetuses with congenital heart disease. Early Hum Dev 2015;91(3): 195-8.

[33] Velayo C, Sato N, Ito T, Chisaka H, Yaegashi N, Okamura K, et al. Understanding congenital heart defects through abdominal fetal electrocardiography: case reports and clinical implications. J Obstet Gynaecol Res 2011;37(5):428-35.

[34] Yilmaz B, Narayan HK, Wilpers A, Wiess C, Fifer WP, Williams IA. Electrocardiographic intervals in foetuses with CHD. Cardiol Young 2016;26(1):84-9. 
[35] Sato M, Kimura Y, Chida S, Ito T, Katayama N, Okamura K, et al. A novel extraction method of fetal electrocardiogram from the composite abdominal signal. IEEE Trans Biomed Eng 2007;54(1):49-58.

[36] Sato N, Hoshiai T, Ito T, Owada K, Chisaka H, Aoyagi A, et al. Successful detection of the fetal electrocardiogram waveform changes during various states of singletons. Tohoku J Exp Med 2011;225(2):89-94.

[37] Chia EL, Ho TF, Rauff M, Yip WC. Cardiac time intervals of normal fetuses using noninvasive fetal electrocardiography. Prenat Diagn 2005;25(7):546-52.
[38] Pardi G, Marconi A, Ferrazzi E. The intraventricular conduction time of fetal heart in pregnancies with suspected fetal growth retardation. Br J Obstet Gynaecol 1986; 93(3):250-4.

[39] Barnes N, Archer N. Understanding congenital heart disease. Curr Paed 2005;15 421-8. 